\title{
THE EFFECT OF DIFFERENT LEVELS OF VITAMIN E ON THE REPRODUCTIVE PERFORMANCE OF ZEBRAFISH (Danio rerio)
}

\section{Pengaruh Pemberian Vitamin E Dengan Level Berbeda Terhadap Kinerja Reproduksi Ikan Zebra (Danio rerio)}

\author{
N. B. P. Utomo, M. Zairin Jr., T. L. Yusuf, I. Mokoginta and M. Bintang \\ Department of Aquaculture \\ Faculty of Fisheries and Marine Science, Bogor Agricultural University, Bogor 16680, Indonesia
}

\begin{abstract}
This experiment was conducted to determine the dietary Vitamin E requirement for reproduction of broodstock zebrafish Danio rerio. Four isonitrogenous (39\% crude protein) and isocaloric $(3,260 \mathrm{kcal}$ digestible energy $/ \mathrm{kg}$ diet) practical diets, namely diets A, B, C, and D with different levels of Vitamin E were fed to zebrafish broodstock. The broodstock were cultivated in aquaria. Diet A contained low dosage of Vitamin E (5 mg Vitamin E $/ \mathrm{kg}$ diet), while diets B (62 mg Vitamin E $/ \mathrm{kg}$ diet), C (125 mg Vitamin E $/ \mathrm{kg}$ diet), and diet $\mathrm{D}$ (187 mg Vitamin $\mathrm{E} / \mathrm{kg}$ diet), combined respectively with $1 \% \mathrm{n}-3$ fatty acids and $2 \% \mathrm{n}-6$ fatty acids. Fish were fed ad satiation for 60 days using these diets. During feeding period, gonad maturation stages were examined. The dietary with different level of Vitamin E affected egg size, chemical content, total number of larvae, normal larvae, and survival rate of larvae produced, fecundity, fertilization rate, and hatching rate. On the other hand, fish fed on experimental diets did not show any significance differences in the gonad somatic index, fecundity, fertilization rate, and hatching rate. Fish fed on diet D produced the highest fecundity $(633.65 \pm 71.86$ eggs/grams of fish), fertilization rate $(92.3 \pm 7.7 \%)$, and hatching rate $(80.31$ $\pm 9.8 \%)$. The total lipid content of eggs were significant, ranging from D (39.7\%), C (33.5\%), B (32.1\%), and A $(29.5 \%)$. At a dosage of $1 \%$ of dietary $n-3$ fatty acids and $2 \% \mathrm{n}-6$ fatty acids, zebrafish require $187 \mathrm{mg}$ Vitamin E/kg feed in the diet for reproduction. .
\end{abstract}

Keywords: vitamin E, reproductive performance, Danio rerio

\begin{abstract}
ABSTRAK
Penelitian ini ditujukan untuk mengetahui kebutuhan Vitamin E pada pakan induk ikan zebra (Danio rerio) untuk reproduksi. Empat pakan perlakuan yang iso-protein (39\%) dan iso-kalori (3.260 kcal digestible energy/kg pakan), dinamakan pakan A, B, C, dan pakan D dengan kandungan Vitamin E yang berbeda diberikan kepada induk ikan zebra. Induk ikan dipelihara pada akuarium. Pakan A mengandung Vitamin $\mathrm{E}$ terendah (5 mg Vitamin E/kg pakan), sedangkan pakan B mengandung Vitamin E $62 \mathrm{mg}$ Vitamin E/kg pakan, pakan C asam mengandung Vitamin E $125 \mathrm{mg} / \mathrm{kg}$ pakan, dan pakan D mengandung Vitamin E $187 \mathrm{mg} / \mathrm{kg}$ pakan. Semua pakan perlakuan mempunyai kombinasi asam lemak n-3 berbanding n-6 sebesar 1:2. Ikan diberi pakan secara ad satiation selama 60 hari pemeliharaan. Selama masa pemberian pakan, tingkat kematangan gonad diperiksa secara teratur. Perbedaan kandungan vitamin E dalam pakan mempengaruhi fekunditas, derajat pembuahan telur, serta derajat penetasan telur. Pakan perlakuan tidak mempengaruhi nilai gonad somatik indeks dan kelangsungan hidup larva umur 3 hari. Pemberian pakan D menghasilkan fekunditas (633.65 \pm 71.86 telur/gram induk), derajat pembuahan telur $(92.3 \pm 7.7 \%)$, serta derajat penetasan telur $(80.31 \pm 9,8 \%)$ terbaik. Total kandungan lemak pada telur berbeda nyata, yaitu pada pakan D (39.7\%), $\mathrm{C}(33.5 \%), \mathrm{B}(32.1 \%)$, dan pakan $\mathrm{A}(29.5 \%)$. Pada kandungan $1 \%$ asam lemak n-3 dan 2\% asam lemak n-6, ikan zebra membutuhkan $187 \mathrm{mg}$ Vitamin E/kg pakan untuk reproduksi yang normal.
\end{abstract}

Kata kunci: Vitamin E, penampilan reproduksi, Danio rerio

\section{INTRODUCTION}

Nutrition is known to have a great influence upon reproductive performance in fish (Fernandez-Palacios et al. 1994;
Izguerdo et al., 2001). The composition of broodstock diet is believed to have profound effects on the reproduction and egg quality of several fish (Watanabe et al., 1984; Fernandez-Palacios et al., 1994; Izguerdo et 
al., 2001). Moreover, for successful development the embryos of fish depend totally on the nutrients stored in the yolk. During the past three decades, considerable attention has been paid to the effects of vitamins $\mathrm{E}$ (tocopherol) in broodstock performance, egg quality, and fry viability of several fish species (Takeuchi et al., 1988). Observed effects of a deficiency of vitamin E include delay in ovarian development and decreased egg hatchability and fry survival (Takeuchi et al., 1988).

Vitamin E, especially its most active form, a-tocopherol, is the major antioxidant present in cell membranes and thus protects cell and organelle membranes from oxidation by reacting with organic free radicals. Previous studies have shown that higher levels of linoleic acid (18:2n-6) and n-6 highly unsaturated fatty acids (HUFA) increased fecundity, egg hatching efficiency and larval quality. Increased levels of HUFA may render membranes more susceptible to oxidation and may increase the requirement for antioxidants. Therefore, it is of interest to assess whether increasing dietary levels of antioxidants would improve broodstock performance when accompanied by high dietary levels of HUFA.

Recently, ornamental fish such as zebrafish (Danio rerio) becomes a popular fish in Indonesia. For this reason, the seed demand was increase (Director General of Aquaculture, 2001). On the other hand, the existing hatcheries could not supply the seeds demand due to the low productivities. In order to improve the performance, good quality of broodstock is necessary. Freshwater fish commonly require vitamin E, but different fish species require differ level group vitamin E (Takeuchi et al., 1996). This experiment was conducted to determine the dietary vitamin E level in practical diet for reproduction of broodstock zebrafish Danio rerio.

\section{MATERIALS AND METHODS}

\section{The Experimental Diets}

Four practical diets were used in this experiment (Table 1). The main protein source was fish meal and the alternative protein source was defatted soybean meal, pollard, and wheat flour. Pollard and wheat flour were used as the carbohydrate sources and binders. The lipid source was a mix of corn oil and coconut oil.

\section{The Broodstock Rearing}

Broodstock fish with body weigh 0,11 $0,13 \mathrm{~g}$ per individual were used in this experiment. Fish were cultivated in aquaria $(30 \times 30 \times 30 \quad \mathrm{~cm})$ under standardized conditions at $26^{\circ} \mathrm{C} \pm 1^{0} \mathrm{C}$. The light/dark cycle was $12 \mathrm{~h} / 12 \mathrm{~h}$ (Maack \& Segner, 2004). Ten females were placed in each aquaria. There were 9 aquaria for 3 treatments/diets.

The fish were fed on the experimental diets four times daily at satiation. During feeding period, gonad maturation stages were examined. The fish start to mature after two months of the feeding trials. Only healthy fish without diseases and abnormalities were used as parental fish for the production of fertilized eggs. The eggs produced by the respected females were fertilized by the milt of males and were incubated in aquaria. Sample of egg and larvae in one aquarium from each female were counted in order to get the hatching rate. This experiment was conducted for 2 months.

\section{Statistical Analysis}

This experiment used a completely randomized design. Gonad somatic index (GSI), fecundity (F), fertilization rate (FR), hatching rate (HR), and total number of larvae produced were subjected to one way analysis of variance and Tuckey's Test to determine significant difference among treatments (Steel \& Torrie, 1980).

\section{Chemical Analysis}

Proximate analysis was done on the experimental diets, and eggs. Moisture, crude ash, crude protein (semi micro-Kjeldahl), crude lipid (Folch method), and carbohydrate were analyzed as described by Takeuchi (1988). The fatty acid compositions were analyzed for experimental diets by using gas liquid chromatography (GLC) as described by Takeuchi (1988). 
Lipid in the diets was extracted using the procedure of Takeuchi (1988). The lipid extracts, was then subjected to acetone extraction to isolate the a-tocopherol. The whole procedure was carried out in a lowlight environment under ice-cold $5^{0} \mathrm{C}$ conditions. The acetone lipid extracts was then dried under nitrogen and the dry residue redissolved in $5 \mathrm{ml}$ of HPLC-grade hexane before samples of this solution $20 \mathrm{ml}$ were injected into a Hitachi L-6200 HPLC and analyzed directly for a-tocopherol. Separation and quantification of a-tocopherol was performed using a $5-\mathrm{mm} 250=4.6 \mathrm{~mm}$ normal phase column (Supelco, Singapore). Alpha-tocopherol was detected 2 at $295 \mathrm{~nm}$ using a Hitachi L-4250 fluorescence detector.

\section{RESULT AND DISCUSSION}

Fecundity, hatching rate, and fertilization rate of diet $\mathrm{D}$ (vitamin $\mathrm{E}=187 \mathrm{mg} / \mathrm{kg}$ diet) was higher than that other diets; but the gonad somatic index and survival rate (3 days old larvae) of all treatments diets were the same (Table 3 ). The broodstock fed on diet $\mathrm{A}$ (vitamin $\mathrm{E}=5 \mathrm{mg} / \mathrm{kg}$ diet) produced the lowest fecundity, hatching rate, and fertilization rate $(\mathrm{P}<0,005)$. Table 4 shows the water and lipid content of egg.

Fecundity is the total number of eggs produced by each fish expressed either in term of eggs/body weight. Reduced fecundity, reported in diet $\mathrm{A}$ (vitamin $\mathrm{E}=5$ $\mathrm{mg} / \mathrm{kg}$ diet) and $\mathrm{B}$ (vitamin $\mathrm{E}=62 \mathrm{mg} / \mathrm{kg}$ diet), could be caused either by the influence of a nutrient imbalance on the brainpituitary-gonad endocrine system or by restriction in the availability of a biochemical component for egg formation (Izguerdo et al., 2001). Indeed, one of the major nutritional factors that have been found to significantly affect reproductive performance in fish is the dietary vitamin $\mathrm{E}$ content (Watanabe et al., 1984). In general, the vitamin $\mathrm{E}$ content of the broodstock diet would affect lipid content of egg produced (Table 4).

Table 1.Composition and proximate analyses of the experimental diets.

\begin{tabular}{|c|c|c|c|c|}
\hline \multirow{2}{*}{ Ingredients } & \multicolumn{4}{|c|}{ Diets/mg Vitamin E/kg diet (\%) } \\
\hline & $\mathbf{A}(\mathbf{0})$ & $\mathrm{B}(62.5)$ & $\mathrm{C}(\mathbf{1 2 5})$ & $\mathrm{D}(\mathbf{1 8 7 . 5 )}$ \\
\hline Fish meal & 31.0000 & 31.0000 & 31.0000 & 31.0000 \\
\hline Soybean meal & 29.0000 & 29.0000 & 29.0000 & 29.0000 \\
\hline Pollard & 20.0000 & 20.0000 & 20.0000 & 20.0000 \\
\hline Fish oil & 3.0000 & 3.0000 & 3.0000 & 3.0000 \\
\hline Corn oil & 2.5000 & 2.5000 & 2.5000 & 2.5000 \\
\hline Vitamin mix ${ }^{*}$ & 2.0000 & 1.9875 & 1.975 & 1.9625 \\
\hline Vitamin E & 0.0000 & 0.0625 & 0.0125 & 0.0187 \\
\hline Mineral mix ${ }^{*}$ & 3.0000 & 3.0000 & 3.0000 & 3.0000 \\
\hline Wheat flour & 9.5000 & 9.5000 & 9.5000 & 9.5000 \\
\hline \multicolumn{5}{|c|}{ Proximate composition (\% dry weight) } \\
\hline Protein & 39.9 & 39.8 & 39.9 & 39.4 \\
\hline Lipid & 10.3 & 10.8 & 10.6 & 10.8 \\
\hline Ash & 8.6 & 8.6 & 8.9 & 8.5 \\
\hline Carbohydrate & 36.4 & 35.5 & 35.3 & 36.2 \\
\hline $\mathrm{DE}(\mathrm{kkal} / 100 \mathrm{~g})^{*}$ & 313.7 & 316.5 & 314.8 & 316.3 \\
\hline $\mathrm{C} / \mathrm{P}$ & 7.8 & 7.9 & 7.8 & 8.0 \\
\hline Vitamin E & 5 & 62 & 125 & 187 \\
\hline
\end{tabular}


Table 2.Chemico-physical water parameters

\begin{tabular}{lcl}
\hline \multicolumn{1}{c}{ Parameter } & Content & \multicolumn{1}{c}{ Water Quality Measurement } \\
\hline Temperature $\left({ }^{\circ} \mathrm{C}\right)$ & $27 \pm 1$ & Thermometer \\
\hline $\mathrm{pH}$ & $8 \pm 0,2$ & $\mathrm{pH}$ meter (Toa Electronics Ltd, Japan; HM-30V) \\
\hline Oxygen $\left(\mathrm{mg} \mathrm{O}_{2} / \mathrm{L}\right)$ & $6,0 \pm 1,5$ & DO meter (Toa Electronics Ltd, Japan; DO-20 A) \\
\hline Ammonia $(\mathrm{ppm})$ & $0,01 \pm 0,001$ & Test Kit (Sera GmbH, Germany; Sera ammonia test) \\
\hline
\end{tabular}

Table 3. The GSI, F, HR, FR, and SR produced by fish during the experimental period.

\begin{tabular}{lcccc}
\hline \multirow{2}{*}{ Parameter } & \multicolumn{4}{c}{ Diets/ mg Vitamin E/kg diet (\%) } \\
\cline { 2 - 5 } & $\mathbf{A}(\mathbf{5})$ & $\mathbf{B}(\mathbf{6 2})$ & $\mathbf{C}(\mathbf{1 2 5})$ & $\mathbf{D}(\mathbf{1 8 7})$ \\
\hline GSI (\%) & $7.92 \pm 4.39^{\mathrm{a}}$ & $9.16 \pm 2.64^{\mathrm{a}}$ & $9.59 \pm 4.52^{\mathrm{a}}$ & $11.34 \pm 5.98^{\mathrm{a}}$ \\
\hline F (eggs/g of fish) & $69.93 \pm 38.78^{\mathrm{a}}$ & $214.60 \pm 98.21^{\mathrm{ab}}$ & $302.34 \pm 131.20^{\mathrm{ab}}$ & $633.65 \pm 71.86^{\mathrm{b}}$ \\
\hline FR (\%) & $77.82 \pm 10.91^{\mathrm{a}}$ & $29.72 \pm 29.01^{\mathrm{a}}$ & $55.36 \pm 39.25^{\mathrm{a}}$ & $92.31 \pm 7.77^{\mathrm{c}}$ \\
\hline $\mathrm{HR}(\%)$ & $39.06 \pm 19.72^{\mathrm{a}}$ & $23.30 \pm 23.17^{\mathrm{a}}$ & $43.03 \pm 38.56^{\mathrm{a}}$ & $80.31 \pm 9.77^{\mathrm{ab}}$ \\
\hline $\mathrm{SR}_{3}(\%)$ & $93.33 \pm 20.00^{\mathrm{a}}$ & $80.00 \pm 11.55^{\mathrm{a}}$ & $80.00 \pm 11.55^{\mathrm{a}}$ & $100.00 \pm 20.00^{\mathrm{a}}$ \\
\hline
\end{tabular}

${ }^{1}$ Values in each row with the same superscript are not significantly different $(\mathrm{p}<0,005)$.

Table 4. The water and lipid content of egg (\% dry weight).

\begin{tabular}{lcccc}
\hline \multirow{2}{*}{ Proximate composition } & \multicolumn{4}{c}{ Diets/ mg Vitamin E/kg diet (\%) } \\
\cline { 2 - 5 } & $\mathbf{A}(\mathbf{5})$ & $\mathbf{B}(\mathbf{6 2})$ & $\mathbf{C}(\mathbf{1 2 5})$ & $\mathbf{D}(\mathbf{1 8 7})$ \\
\hline Water & 63,5 & 66,8 & 65,5 & 65,0 \\
\hline Lipid & 29,5 & 32,1 & 33,5 & 39,7 \\
\hline
\end{tabular}

The lipid content of egg from diets D (vitamin $\mathrm{E}=187 \mathrm{mg} / \mathrm{kg}$ diet) $39.7 \%$ was higher than that of diets $\mathrm{C}$ (vitamin $\mathrm{E}=125$ $\mathrm{mg} / \mathrm{kg}$ diet) $33.5 \%$, diets $\mathrm{B}$ (vitamin $\mathrm{E}=62$ $\mathrm{mg} / \mathrm{kg}$ diet) $32.1 \%$ and diets $\mathrm{A}$ (vitamin $\mathrm{E}=5$ $\mathrm{mg} / \mathrm{kg}$ diet) $29.5 \%$. Vitamin $\mathrm{E}$ in the broodstock diets also affected hatching rate and fertilization rate. During embryogenesis and larvae development, lipid was used as a source of energy; and egg of diet D (Table 4) had the highest energy reserve. So, vitamin E in diets would determine the success of embryogenesis, which could be seen in the value of hatching rate.

Vitamin E, especially its most active form, $\alpha$-tocopherol, is the major antioxidant present in cell membranes and thus protects highly unsaturated fatty acids (HUFA) from oxidation by reacting with organic free radicals. Previous studies have shown that higher levels of linoleic acid (18:2n-6) and n6 highly unsaturated fatty acids (HUFA) increased fecundity, egg hatching efficiency and larval quality. Increased levels of HUFA may render membranes more susceptible to oxidation and may increase the requirement for antioxidants. Therefore, it is of interest to assess whether increasing dietary levels of antioxidants would improve broodstock performance when accompanied by high dietary levels of HUFA. Other function of the essential fatty acid (HUFA) has a role as a precursor of prostaglandin (Leray et al., 1985). Prostaglandins (PGs) are also 
recognized as important pheromones in some teleost fish. Some PGs produced by female fish, such as PGFs, have been shown to stimulate male sexual behaviour and synchronize male and female spawning, thus directly affecting the success in fertilization (Sorensen et al., 1988).

\section{ACKNOWLEDGEMENT}

Sincere gratitude is extended to the Department of National Education, Indonesia, for supporting this research project.

\section{REFERENCES}

Fernandez-Palacios, H. Izguerdo, M.S.Robaina, L. Valencia, A. Salhi, and Vergara, J.M. 1994. Effect of n-3 HUFA level in broodstock diets on egg quality of gilthead sea bream (Sparus aurata L.). Aquaculture, 132: 325-337.

Izquierdo, M.S., H. Fernandez-Palacios, A.G.J. Tacon. 2001. Effect of broodstock nutrition on reproductive performance of fish. Aquaculture, 197: 25-42

Leray, C., G. Nonnotte, P. Roubaud and C. Leger. 1985. Incidence of n-3 essential fatty acid efficiency on trout reproductive process. Reproduction Nutrition Development, 25:256-581

Maack, G and H. Segner. 2004. The gonadal development of the zebrafish (Danio rerio), Ham. Buc. hhtp://www.Igb_berlin.com. 25 May 2004.

Sorensen, P.W., Hara, T.J., Stacey, N.E., Goetz, F.W. 1988. F prostaglandins function as potent stimulants that comprise the post-ovulatory female sex pheromone in goldfish. Biol.Reprod., 39:1039-1050

Steel, R.G.D. and J.H. Torrie. 1980. Principles and procedures of statistics. Biometrical Approach. McGraw-Hill Book Company. 633 p.

Takeuchi, T. 1988. Laboratory work chemical evaluation of dietary nutrients. p. 179-225. In: Fish nutrition and mariculture. Watanabe, T. (ed.). Department of Aquatic Bioscience. Tokyo University of Fisheries. JICA.

Watanabe, T., T. Arakawa, C. Kitajima and S. Fujita. 1984. Effect of nutritional quality of broodstock diets on reproduction of red sea bream. Nippon Suisan Gakkaishi, 50:495. 